\title{
PENGARUH MOTIVASI GURU \\ TERHADAP PRESTASI BELAJAR SISWA \\ MATA PELAJARAN IPS DI SDN RAJAGALUH KIDUL \\ KEC. RAJAGALUH KAB. MAJALENGKA
}

Oleh:

Drs. H. S. Bunyamin, M.Pd

Diah Faujiah

\begin{abstract}
Abstrak
Motivasi guru sangat berpengaruh terhadap peningkatan prestasi siswa dalam belajar di sekolah. Hal ini merupakan salah satu ciri bahwa proses pendidikan dikatakan tercapai apabila siswa mampu membuktikannya dengan sebuah prestasi yang cukup baik. Tinggi rendahnya prestasi belajar siswa salah satunya dipengaruhi oleh motivasi guru dalam belajar baik disekolah maupun dirumah.

Tujuan dari penelitian ini adalah untuk mengetahui seberapa baik penggunaan motivasi guru pada pembelajaran IPS, untuk mengetahui seberapa besar prestasi belajar siswa pada pelajaran IPS, dan untuk mengetahui seberapa besar pengaruh motivasi guru terhadap prestasi belajar IPS. Penelitian ini dilakukan di SDN Rajagaluh Kidul II, Jalan Cakra Ningrat Desa Rajagaluh Kidul, Kecamatan Rajagaluh Kabupaten Majalengka.

Motivasi guru merupakan salah satu faktor yang menentukan prestasi belajar siswa. Karena dengan adanya motivasi dari guru maka tumbuhlah minat seorang siswa untuk terus belajar demi tercapainya cita-cita sesuai dengan apa yang diinginkannya. Motivasi jika dikombinasikan dengan proses belajar serta ditunjang oleh gaya belajar, metode, media maupun sarana dan prasarana yang lainnya yang cukup memadai tentu akan menghasilkan output yang berkualitas. Profesionalisme guru dalam mengajar dan mendidik juga menjadi faktor pendukung keberhasilan siswa.

Penelitian ini menggunakan pendekatan kuantitatif, karena hasil dari penelitian yang telah dilakukan berupa angka-angka. Penelitian kuantitaif adalah metode untuk menguji teori-teori tertentu dengan cara meneliti pengaruh antar variabel. Variabel-variabel ini diukur (biasanya dengan instrument penelitian) sehingga data yang terdiri dari angka-angka dapat dianalisis berdasarkan prosedur statistik serta prosesnya diteliti secara detail. Sumber penelitiannya yaitu siswa kelas V SDN Rajagalu Kidul II yang berjumlah 31 siswa.

Hasil penelitian menunjukkan bahwa motivasi guru berpengaruh terhadap prestasi belajar IPS siswa, hal ini dibuktikan dari perhitungan uji korelasi 0,679 yang artinya terdapat hubungan antara motivasi guru terhadap prestasi belajar.
\end{abstract}


Dapat disimpulkan bahwa motivasi guru mempengaruhi prestasi belajar siswa sebesar 44,1\% sementara sisanya 55,9\% dipengaruhi oleh variabel lain.

\section{Kata kunci : Motivasi Guru, Prestasi Belajar Siswa}

\section{A. Pendahuluan}

Pada kegiatan belajar mengajar banyak siswa yang kehilangan semangat belajarnya. Hal ini dapat disebabkan karena kurangnya motivasi yang dimiliki siswa dalam belajar. Sekolah merupakan lembaga yang tepat untuk menghasilkan manusia yang berkompeten dan memiliki daya sains. Salah satunya yaitu motivasi siswa dalam belajar untuk mencapai pendidikan nasional.

Motivasi merupakan suatu kondisi yang dimiliki oleh setiap siswa untuk bertingah laku. Potensi yang dimiliki siswa berbeda-beda, begitu juga dengan cara mengembangkan potensi yang dimiliki. Cara mengembangkan bergantung kepada keinginan yang dimiliki oleh setiap siswa. Hal ini dipengaruhi oleh motivasi setiap pribadi masing-masing. Mc. Donald (Oemar Hamalik, 2001: 158) mendefinisikan motivasi adalah perubahan energi dalam diri (pribadi) seseorang yang ditandai dengan timbulnya perasaan dan reaksi untuk mencapai tujuan.

Pentingnya guru dalam memberikan motivasi kepada siswanya yaitu untuk menumbuhkan minat belajar siswa, dalam skripsi ini yaitu motivasi guru terhadap prestasi belajar siswa mata pelajaran IPS yaitu dengan cara mempersiapkan pengajaran IPS dengan baik sehingga dapat dirasakan penting dan menarik untuk siswa, guru harus dapat menciptakan suasana kelas yang merangsang siswa untuk mau belajar, guru tidak boleh mengeluh dan bosan untuk selalu memberi penguatan kepada siswa bahwa belajar IPS itu sesulit seperti yang dibayangkan asalkan kita mau belajar, berani mencoba dan tidak takut salah atau tidak takut untuk gagal.

Selain itu juga, guru sebagai motivator harus mampu terampil dalam membuat alat peraga pembelajaran yang sederhana sesuai dengan kebutuhan, selain itu terampil juga dalam menerapkan metode yang tepat dalam setiap pembelajaran tentunya disesuaikan dengan materi yang akan disampaikan 
yang diberikan dengan baik dan benar. Guru juga dapat memberikan motivasi kepada siswa untuk meningkatkan prestasi belajar siswa. Prestasi belajar ini merupakan hasil yang mengakibatkan perubahan dalam diri individu sebagai hasil dari aktivitas belajar. Hasil atau taraf kemampuan yang telah dicapai siswa setelah melalui proses belajar mengajar dalam waktu tertentu baik berupa perubahan perilaku, keterampilan atau pengetahuan dapat diukur dan dinilai dengan angka atau pernyataan.

Motivasi guru sangat berpengaruh terhadap peningkatan prestasi siswa dalam belajar di sekolah. Hal ini merupakan salah satu ciri bahwa proses pendidikan dikatakan tercapai apabila siswa mampu membuktikannya dengan sebuah prestasi yang cukup baik. Tinggi rendahnya prestasi belajar siswa salah satunya dipengaruhi oleh motivasi guru dalam belajar baik disekolah maupun dirumah.

Sesuai dengan observasi yang telah dilakukan oleh peneliti di SDN Rajagaluh Kidul 2 Kecamatan Rajagaluh Kabupaten Majalengka, khususnya guru kelas V di SDN Rajagaluh Kidul 2 telah memenuhi syarat sebagai guru propesional sebagaimana yang telah tercantum dalam Undang-Undang Guru dan Dosen Tahun 2005 yang salah satunya yaitu telah memiliki kualifikasi akademik sarjana (S1). Dan setiap akan melaksanakan pembelajaran guru diwajibkan untuk mempersiapkan administrasi dengan lengkap, seperti: pembuatan RPP, Silabus, Promes dan Prota. Akan tetapi, masih ada saja siswa yang mendapatkan nilai yang dibawah standar KKM, terutama pada mata pelajaran (IPS) Ilmu Pengetahuan Sosial.

Berdasarkan hal tersebut di atas maka peneliti tertarik untuk meneliti bagaimana pengaruh motivasi guru terhadap prestasi belajar siswa mata pelajaran IPS di SDN Rajagaluh Kidul II Kecamatan Rajagaluh Kabupaten Majalengka?

Tujuan dari penelitian ini adalah untuk mengetahui seberapa baik penggunaan motivasi guru pada pembelajaran IPS, untuk mengetahui seberapa besar prestasi belajar siswa pada pelajaran IPS, dan untuk mengetahui seberapa besar pengaruh motivasi guru terhadap prestasi belajar 
IPS. Penelitian ini dilakukan di SDN Rajagaluh Kidul II, Jalan Cakra Ningrat

Desa Rajagaluh Kidul, Kecamatan Rajagaluh Kabupaten Majalengka.

\section{B. Landasan Teori}

\section{Motivasi}

Motivasi guru merupakan salah satu faktor yang menentukan prestasi belajar siswa. Karena dengan adanya motivasi dari guru maka tumbuhlah minat seorang siswa untuk terus belajar demi tercapainya citacita sesuai dengan apa yang diinginkannya. Motivasi jika dikombinasikan dengan proses belajar serta ditunjang oleh gaya belajar, metode, media maupun sarana dan prasarana yang lainnya yang cukup memadai tentu akan menghasilkan output yang berkualitas. Profesionalisme guru dalam mengajar dan mendidik juga menjadi faktor pendukung keberhasilan siswa.

Selain daripada itu faktor lingkungan pun sangat berpengaruh, baik itu dari lingkungan keluarga, lingkungan sekolah, maupun lingkungan teman sepermainannya. Dari sebab faktor-faktor diatas saling berkaitan antara yang satu dengan yang lainnya. Namun dari ketiga faktor lingkungan diatas yang mempunyai peran sangat penting yaitu faktor lingkungan keluarga, tidak dapat dipungkiri waktu yang paling banyak dihabiskan oleh siswa yaitu waktu bersama keluarga. Oleh sebab itu selain motivasi guru yang diberikan kepada siswa diharapkan setiap orang tua pun mampu memotivasi belajar anak-anakanya sehingga timbul kesadaran dari diri siswa itu sendiri untuk giat belajar dan kelak dapat meraih apa yang telah menjadi cita-citanya.

Prestasi belajar yang dicapai seseorang merupakan hasil interaksi dari berbagai faktor yang mempengaruhinya baik dari dalam diri (faktor intrinsik) individu antara lain minat, kecerdasan, bakat, motivasi dan kemampuan kognitif, sedangkan faktor dari luar diri (faktor ekstrinsik) individu antara lain faktor lingkungan yaitu alam, sosial budaya dan keluarga dan faktor instrumental yaitu kurikulum, program, sarana dan 
fasilitas dan guru (Djamarah, 2002:144).

Motivasi belajar selain diperoleh dari guru dan orang tua dapat pula timbul karena adanya faktor intrinsik yang berupa hasrat keingintahuan dan kainginan untuk berhasil serta dorongan kebutuhan belajar harapan akan cita-cita. Sedangkan faktor ekstrinsiknya yaitu berupa adanya pemberian penghargaan, lingkungan belajar yang mendukung dan kegiatan belajar yang menarik. Dari sinilah diharapkan adanya perubahan yang dapat dilihat dari prestasi belajar yang dihasilkan siswa. Jadi dari pemikiran diatas dapat disimpulkan bahwa motivasi guru sangat erat hubungannya degan prestasi belajar siswa.

Motivasi merupakan salah satu determinan penting dalam belajar, para ahli sukar mendefinisikannya, akan tetapi motivasi berhubungan dengan arah perilaku, kekuatan respon setelah belajar siswa memilih mengikuti tindakan tertentu, ketahan perilaku atau beberapa lama seseorang itu terus menerus berperilaku menurut cara tertentu ( Martinis Yamin, 2007: 157).

Menurut Djamarah, (2008: 148) Motivasi adalah suatu perubahan energi di dalam pribadi seseorang yang ditandai dengan timbulnya reaksi afektif. Perubahan energi dalam diri seseorang itu berbentuk suatu aktivitas nyata berupa kegiatan fisik.Karena seseorang mempunyai tujuan tertentu dari aktivitasnya, maka seseorang mempunyai motivasi yang kuat untuk mencapainya.

Untuk mengetahui motivasi guru, maka akan dikemukakan beberapa pendapat mengenai fungsi motivasi, Sardiman (2001: 83) Fungsi motivasi sebagai berikut:

a. Mendorong mausia untuk berbuat, jadi sebagai penggerak atau motor yang melepaskan energi.

b. Menentukan arah perubahan yakni kearah tujuan yang hendak dicapai.

c. Menyeleksi perbuatan yakni menentukan perbuatan-perbuatan apa yang harus dikerjakan yang serasi guna mencapai tujuan, dengan menyisihkan perbuatan yang tidak bermanfaat tersebut. 
Dari pendapat diatas dapat dikembangkan bahwa fungsi motivasi yaitu:

a. Mendorong manusia untuk bertindak, yaitu berfungsi sebagai penggerak atau motor yang memberikan energi (kekuatan) kepada seseorang untuk melakukan tugas.

b. Menentukan arah perbuatan, yaitu kearah suatu tujuan atau cita-cita, mencegah adanya penyelewengan dari jalan yang harus ditempuh untuk mencapai tujuan. Makin jelas tujuannya maka makin jelas pula jalan harus ditempuh.

c. Menyeleksi perbuatan, yaitu menentukan perbuataan-perbuatan yang perlu diseleksi maa yang bermanfaat atau berguna atau mana yang tidak bermanfaat.

d. Sebagai pendorong untuk memperoleh prestasi melalui kerja keras secara optimal.

Adapun tujuan dari motivasi guru adalah untuk memenuhi kebutuhan hidup siswa khususnya dalam hal belajar, seperti (1) kebutuhan untuk melakukan sesuatu sebagai aktivitas belajar dalam rangka mencapai prestasi yag diharapkan, (2) kebutuhan untuk menyenangkan hati orang lain, dan (3) kebutuhan untuk mengatasi masalah.

Dari uraian diatas dapat disimpulkan bahwa motivasi bertujuan untuk meningkatkan kreativitas dan produktivitas siswa, sehingga dapat lebih mendorong dan bersemangat untuk bekerja atau melaksanakan kewajibannya.

Motivasi memiliki peranan penting dalam kegiatan individu dalam hal ini yaitu siswa agar kegiatan yang individu itu memberikan hasil yag efektif maka perlu adanya motivasi yang kuat dan untuk itu perlu adanya usaha untuk membangkitka motivasi. Jadi motivasi adalah usaha-usaha untuk menyediakan kondisi dan situasi sehingga individu melakukan kegiatan yag dapat dilakukannya. 
Mengenai jenis-jenis motivasi, menurut Djamarah (2008: 159-151) dan Sardiman (2000: 87-89) yang menyatakan bahwa motivasi secara garis besarnya dibedakan menjadi 2 bagian yaitu (1) motivasi Intrinsik. Motivasi ini berasal dari dalam diri setiap individu yang sudah memiliki dorongan dengan sendirinya untuk melakukan suatu kegiatan.Misalnya seirang siswa tanpa harus diperintah atau dipaksa melainkan atas kesadaran sendiri dia melaksanakan kewajibaanya sebagai siswa, dan (2) motivasi ekstrinsik. Motivasi ini berfungsi karena ada perangsang dari luar. Seorang siswa mau melaksanakan belajar apabila dia disuruh atau akan diberikan fasilitas atau semacamnya oleh orang tuanya, walaupun demikian motivasi ini tetap diperlukan.

Menurut Syamsudin (1990: 40) meskipun motivasi merupakan suatu kekuatan, namun tidaklah merupakan subtansi yang secara eksplisit dapat diamati. Namun pengamatannya dapat dilakukan dengan mengidentifikasi beberapa indikator dalam term-term tertentu. Penulis menguti dari beberapa ahli, bahwa indikator motivasi dibagi menjadi delapan yaitu:

a. Durasi kegiatan

Yaitu kemampuan penggunaan waktu untuk melakukan kegiatan secara efektif dan efisien.

b. Frekuensi Kegiatan

Yaitu sering kali kegiatan yang dilakukan dalam periode waktu tertentu.

c. Persistansi (ketetapan dan kelekatannya) pada tujuan kegiatan

Siswa yang memahami dan mengetahui tujuan dari suatu kegiatan yang hendak dicapai merupakan motivasi yang baik, karena dengan mengetahui tujuan yang hendak dicapai siswa akan lebih bersemangat dan bergairah dalam belajar.

d. Ketabahan, keuletan, dan kemampuan siswa dalam menghadapi rintangan, kesulitan, untuk mencapai tujuan.

e. Devosi (pengabdian) dan pengorbanan 
Usaha untuk meraih tujuan memerlukan ketekunan dan pengorbanan baik dari segi tenaga, fikiran waktu, harta bahkan nyawa. Setiap perjuangan pasti ada pengorbanan, sebab tanpa pengorbanan perjuangan tidak akan berhasil.

f. Tingkat aspirasi

Yaitu rencana, cita-cita, saran da idolanya yang hendak dicapai dengan kegiatan yang dilakukan.

g. Tingkat kualifikasi prestasi

Kualifikasi dapat diartikan ptoduk atau output yang ingin dicapai dari suatu kegiatan.

h. Arah sikap terhadap sasaran kegiatan

Arah sikap terhadap kegiatan ditentukan oleh tingkat kevaliditasan sasaran yang hendak dicapai sesuai dengan kemauan dan kebutuhan yang diharapkan.

Bentuk kongkrit guru dalam memberikan motivasi kepada siswa yaitu dimulai pada saat guru membuka pelajaran, guru selalu memberikan salam semangat kepada siswa yang dimaksudkan untuk menumbuhkan semangat belajar siswa, ketika belajar guru menggunakan buku-buku yang relevan dan metode yang bervariasi serta media belajar yang disesuaikan dengan materi yang akan diajarkan.

Disela-sela saat pelajaran berlangsung pun guru memberikan saran atau masukan kepada siswa bahwa pelajaran IPS tidak sesulit yang mereka bayangkan, asalkan mau belajar, berani mencoba dan tidak mudah putus asa ketika mengalami kegagalan. Selain itu juga guru tidak bosan untuk mengingatkan siswa bahwa materi yang akan dipelajari di esok hari hendaknya materi tersebut dipelajari terlebih dahulu dirumah, sehingga pada saat proses pembelajaran berlangsung ketika guru menerangkan siswa dapat mengikuti materi yang sedang diterangkan guru dengan baik serta mudah dipahami.

Motivasi yang ada pada diri seseorang dipengaruhi oleh diri sendiri maupun dari luar. Ada teori yang mengatakan bahwa motivasi 
adalah "pendorong" suatu usaha yang disadari untuk mempengaruhi tingkah laku seseorang agar tergerak hatinya untuk bertindak dalam melakukan sesuatu sehingga mencapai hasil atau tujuan tertentu.

Dengan kata lain dapat dikatakan bahwa seseorang termotivasi karena adanya dorongan dari dalam dirinya (siswa) yaitu melalui belajar yang baik maka akan melahirkan keinginan untuk memiliki motivasi yang baik, sehingga tujuan pendidikan dapat tercapai dengan baik. Dengan motivasi inilah siswa menjadi tekun dalam proses belajar, dengan motivasi juga kemungkinan kualitas prestasi belajar siswa dapat diwujudkan.

Bagaimanapun sempurnanya metode yang digunakan oleh guru ketika proses belajar mengajar. Namun jika motivasi belajar siswa kurang atau bahkan tidak ada, maka siswa tidak akan mau belajar yang akan mengakibatkan prestasi belajar tidak akan tercapai. Sehingga apabila motivasi belajar siswa tinggi, diharapkan prestasi belajarnya pun tinggi, demikian pula sebaliknya.

Pembelajaran tidak akan bermakna jika para siswa tidak termotivasi untuk belajar. Dengan demikian, guru harus berupaya sekeras mungkin untuk meningkatkan motivasi belajar siswa dalam proses pembelajaran, seperti berikut ini:

a. Menjelaskan tujuan belajar kepada siswa. Pada permulaan belajar mengajar seharusnya terlebih dahulu guru menjelaskan mengenai Tujuan Intruksional Khusus (TIK) pembelajaran yang akan dicapai oleh siswa. Semakin jelas tujuan maka akan semakin jelas pula motivasi dalam belajar.

b. Hadiah. Berikan hadiah kepada siswa yang berprestasi. Hal ini akan memicu semangat mereka untuk mengejar siswa yang berprestasi. Ada bermacam-macam hadiah, yaitu ada yang berbentuk simbol, penghargaan, kegiatan dan benda.

c. Saingan/kompetensi. Guru berusaha mengadakan persaingan diantara siswanya untuk meningkatkan prestasi belajarnya. Serta 
dberusaha memperbaiki hasil prestasi yang telah dicapai sebelumnya.

d. Pujian. Sudah sepantasnya siswa yang berprestasi diberikan penghargaan atau pujian yang bersifat membangun.

e. Hukuman. Hukuman diberikan kepada siswa yang berbuat kesalahan saat proses belajar mengajar. Hukuman ini diberikan dengan harapan agar siswa yang bersangkutan mau berubah dan berusaha kearah yang lebih baik.

f. Meningkatkan dorongan kepada siswa untuk belajar. Strateginya adalah dengan memberikan perhatian maksimal kepada siswa.

g. Membentuk kebiasaan belajar yang baik.

h. Membantu kesulitan belajar siswa secara individual maupun kelompok.

i. Menggunakan metode yang bervariasi.

j. Menggunakan media yang baik, serta harus sesuai dengan tujuan pembelajaran (M. Sobry Sutikno, 2008: 75-79).

Di dalam dunia pendidikan, guru adalah seorang pendidik, pembimbing, pelatih, dan pengembang kurikulum yang dapat menciptakan kondisi dan suasana belajar yang kondusif, yaitu suasana belajar menyenangkan, menarik, memberi rasa aman, memberikan ruang pada siswa untuk berpikir aktif, kreatif, dan inovatif dalam mengeksplotasi dan mengelaborasi kemampuannya.

Guru yang profesional merupakan faktor penentu proses pendidikan yang berkualitas. Mengomentari mengenai rendahnya kualitas pendidikan saat ini, merupakan indikasi perlunya keberadaan guru profesional. Guru dalam era teknologi informasi dan komunikasi sekarang ini bukan hanya sekedar mengajar (transfer of knowledge) melainkan harus menjadi manajer belajar.

Dalam menjalankan kewenangan profesionalnya, guru dituntut memiliki keanekaragaman kecakapan (competencies) yang bersifat psikologis, yang meliputi (1) kompetensi kognitif (kecakapan ranah 
cipta), (2) kompetensi afektif (kecakapan ranah rasa), dan (3) kompetensi psikomotor (kecakapan ranah karsa).

Disamping itu, ada satu macam kompetensi yang diperlukan oleh seorang guru yaitu kompetensi kepribadian.(Muhibbin, Syah 1995: 231).

\section{Mata Pelajaran IPS di SD}

IPS merupakan salah satu mata pelajaran yang diberikan di SD yang mengkaji seperangkat peristiwa, fakta, konsep, dan generalisasi yang berkaitan dengan isu sosial.Memuat materi geografi, sejarah, sosiologi, dan ekonomi.Melalui mata pelajaran IPS, anak diarahkan untuk dapat menjadi warga negara Indonesia yang demokratis, betanggung jawab, serta warga dunia yang cinta damai.

Mata pelajaran IPS disusun secara sistematis, komprehensif, dan terpadu dalam proses pembelajaran menuju kedewasaan dan keberhasilan dalam kehidupan di masyarakat. Dengan pendekatan tersebut diharapkan anak akan memperoleh pemahaman yang lebih luas dan mendalam pada bidang ilmu yang berkaitan.

Sesuai dengan karakteristik anak dan IPS SD, maka metode ekspositori akan menyebabkan siswa bersikap pasif, dan menrunkan derajat IPS menjadi pelajaran hafalan yang menbosankan. Guru yang bersikap memonopoli peran sebagai sumber informasi, selayaknya meningkatkan kinerjanya dengan metode pembelajaran yang bervariasi, seperti menyajikan cooperative learning model; role playing, jigsaw, membaca sajak, buku (novel), atau surat kabar/majalah/jurnal agar siswa aktif, kreatif, efektif dan menyenangkan (PAKEM) yang memungkinkan anak mengerjakan kegiatan yanf beragam untuk mengembangkan keterampilan, sikap dan pemahaman dengan penekanan belajar sambil bekerja, sementara guru menggunakan berbagai sumber dan alat bantu belajar termasuk pemanfaatan lingkungan supaya pembelajaran lebih menarik, menyenangkan dan efektif. Tentu saja guru harus menimba ilmunya dan melatih keterampilannya, agar ia mampu menyajikan pembelajaran IPS SD dengan menarik. 
Mata pelajaran IPS bertujuan agar anak didik memiliki kemampun sebagai berikut:

a. Mengenal konsep-konsep yang berkaitan dengan kehidupan masyarakat dan lingkungannya.

b. Memiliki kemampuan dasar untuk berpikir logis dan kritis, rasa ingin tahu, inkuiri, memecahkan masalah, dan keterampilan dalam kehidupan sosial.

c. Memiliki komitmen dan kesadaran terhadap nilai-nilai sosial dan kemanusiaan.

d. Memiliki kemampuan berkomunikasi, bekerjasama dan berkompetisi dalam masyarakat yang majemuk, ditingkat lokal, nasional dan global.

Ruang lingkup mata pelajaran IPS meliputi aspek-aspek sebagai berikut, (1) manusia,tempat, dan lingkungan, (2) waktu, keberlanjutan, dan perubahan, (3) sistem sosial dan budaya, dan (4) perilaku ekonomi dan kesejahteraan.

IPS SD sebagai Pendidikan Global (global education), yakni: Mendidik siswa akan kebhinekaan bangsa, budaya, dan peradaban di dunia; Menanamkan kesadaran ketergantungan antar bangsa; Menanamkan kesadaran semakin terbukanya komunikasi dan transportasi antar bangsa di dunia; Mengurangi kemiskinan, kebodohan dan perusakan lingkungan.

\section{Belajar dan Prestasi Belajar}

Menurut Mahmud (2006: 62) Dalam pengertian psikologi, belajar merupakan suatu proses yang bersifat internal. Perubahan yang menjadi fokus pengertian belajar tidak dapat terlihat secara kasat mata, dalam arti konkrit.Ia terjadi dalam diri seseorang yang sedang mengalami proses belajar. Proses perubahan yang dimaksud pada wilayah sikap, kecerdasan motorik dan sensorik, dan keadaan psikis.Yang terlihat secara kasat mata adalah hasil perubahan.Yag diakibatkan dari pengalaman dan latihan. 
Belajar menurut Djamarah (2008: 13) yaitu serangkaian kegiatan jiwa raga untuk memperoleh suatu perubahan tingkah laku sebagai hasil dari pengalaman individu dalam interaksi dengan lingkungannya yang menyangkut kognitif, afektif dan psikomotor.

Jadi dari beberapa pendapat para ahli terkait dengan pengertian belajar yang dipaparkan diatas dapat ditarik kesimpulan bahwa belajar adalah suatu aktivitas nyata yang sengaja dilakukan oleh seseorang dalam hal ini adalah anak didik dengan berulang-ulang dan tidak lepas dari interaksi langsung dengan lingkungannya dengan tujuan untuk membuat perubahan dalam dirinya yang nantinya akan menghasilkan perubahan baik dari sisi pengetahuan, sikap, serta pola pikirnya.

Secara sederhana belajar juga dapat diartikan sebagai aktivitas yang dilakukan secara sadar oleh anak didik untuk melakukan sesuatu yang tadinya tidak bisa menjadi bisa tentunya dengan cara berulangulang dengan mendapatkan bimbingan baik itu dari guru ataupun dari orang tua.

Prestasi belajar merupakan hasil belajar dapat diukur dengan evaluasi, mengukur prestasi belajar lazimnya dilakukan dengan menggunakan alat tes, dengan alat tes tersebut diketahui suatu perkiraan kuantitatif dari prestsi tersebut.Tes hasil belajar yang lazim dipakai berbentuk tes formatif, tes sumatif, tes diagnostik, tes belajar akhir dan sebagainya.Pengukuran prestasi belajar diberikan nilai agar memberikan arti.

Sejalan dengan pendapat Caroll, sebagaimana yang dikutip oleh Sudjana (2000: 240) bahwa hasil belajar yang dicapai siswa dipengaruhi oleh lima faktor, yakni (1) bakat belajar, (2) waktu yang tersedia untuk belajar, (3) waktu yang dipengaruhi untuk menjelaskan pelajaran, (4) kemampuan individu, dan (5) kualitas pengajaran disekolah.

Selanjutnya beliau menjelaskan bahwa empat faktor tersebut diatas $(1,2,3,4)$ berkenaan dengan kemampuan individu dan faktor 5 dari luar individu (lingkungan). 
Dari teori diatas, penulis menyimpulkan bahwa faktor yang mempengaruhi prestasi belajar itu terdiri dari dua faktor yaitu faktor internal dan eksternal. Yang termasuk kedalam faktor internal misalnya dari dalam diri siswa sendiri, sedangkan yang termasuk kedalam faktor eksternalnya misalnya lingkungan serta perhatian dari orang tua. Sehingga apabila prestasi belajar siswa tinggi tujuan belajarnya pun akan tercapai.

\section{Hasil Penelitian dan Pembahasan}

Penelitian ini menggunakan pendekatan kuantitatif, karena hasil dari penelitian yang telah dilakukan berupa angka-angka. Penelitian kuantitaif adalah metode untuk menguji teori-teori tertentu dengan cara meneliti pengaruh antar variabel. Variabel-variabel ini diukur (biasanya dengan instrument penelitian) sehingga data yang terdiri dari angka-angka dapat dianalisis berdasarkan prosedur statistik serta prosesnya diteliti secara detail. Sumber penelitiannya yaitu siswa kelas V SDN Rajagalu Kidul II yang berjumlah 31 siswa.

Hasil penelitian menunjukkan bahwa cara guru dalam memotivasi siswa pada pembelajaran IPS di SDN Rajagaluh Kidul II telah dilaksanakan dengan cukup baik, berdasarkan angket yang diperoleh bahwa jumlah skor hasil pengumpulan data $=1445$. Dengan demikian penerapan motivasi guru pada Mata pelajaran IPS di Kelas V SDN Rajagaluh Kidul II, menurut 31 responden, yaitu $(1445: 1860) \times 100 \%=77,69 \%$ dari kriterium yang ditetapkan. Apabila diinterpretasi nilai 77,69\% terletak pada daerah kuat.

Prestasi belajar siswa dalam pembelajaran IPS dengan jumlah sampel 31 orang didapatkan data bahwa siswa yang mendapatkan nilai 5 sebanyak 2 orang atau 6,5\%, siswa yang mendapatkan nilai 6 sebanyak 2 orang atau $6,5 \%$, siswa yang mendapatkan nilai 7 sebanyak 8 orang atau $35,8 \%$, siswa yang mendapatkan nilai 8 sebanyak 8 orang atau $35,8 \%$, siswa yang mendapatkan nilai 9 sebanyak 7 orang atau 22,6\%, dan siswa yang 
mendapatkan nilai 10 sebanyak 4 orang atau 12,9\%, yang menjadi nilai rataratanya adalah 7,9 berada pada kriterium baik.

Motivasi guru berpengaruh terhadap prestasi belajar IPS siswa, hal ini dibuktikan dari perhitungan uji korelasi 0,679 yang artinya terdapat hubungan antara motivasi guru terhadap prestasi belajar. Dapat disimpulkan bahwa motivasi guru mempengaruhi prestasi belajar siswa sebesar 44,1\% sementara sisanya 55,9\% dipengaruhi oleh variabel lain selain variabel yang digunakan dalam penelitian. 


\section{DAFTAR PUSTAKA}

Abin, Syamsudin. 1990. Kurikulum dan Pembelajaran, Fakultas Tarbiyah dan Keguruan UIN SGD. Bandung.

Anas, Sudijono. 2001. Pengantar Evaluasi Pendidikan. Jakarta: PT. Raja Grafindo Persada.

Arikunto, Suharsimi. 2003. Dasar-Dasar Evaluasi Pendidikan Edisi Revisi. Jakarta: PT. Rineka Cipta. . 2005. Prosedur Suatu Pendekatan Praktek. Jakarta: PT. Rineka Cipta.

Djamarah, Syaiful Bahri. 2008. Psikologi Belajar Edisi 2. Jakarta: Rineka Cipta.

Ginting, Abdorrakhman. 2008. Belajar \& Pembelajaran Edisi Revisi. Bandung: Humaniora.

Hasan, Iqbal. 2002. Pokok-pokok Materi Metodologi Penelitian dan Aplikasinya. Bogor: Ghalia Indonesia. . 2003. Pokok-pokok materi Statistik 1. Jakarta: Grafika Offset. . 2009. Analisis Data Penelitian dengan Statistik. Jakarta: Bumi Aksara.

Mahmud. 2006. Psikologi Pendidikan Mutakhir. Bandung: sahifa

Mulyasa, E. 2006.Kurikulum Tingkat Satuan Pendidikan. Bandung: PT. Remaja Rosdakarya.

Priyanto, Duwi. 2011. Buku Saku SPSS: Analisa Statistik Lebih Cepat, Mudah, dan Akurat. Yogyakarta: MediaKom.

Riduwan. 2003. Dasar-dasar Statistik. Bandung: Alfabeta.

Riduwan. 2008. Belajar Mudah Penelitian Pendidikan Untuk Guru, Karyawan, dan Peneliti Pemula. Bandung: Alfabeta.

Riduwan. 2012. Dasar-dasar Statistik. Bandung Alfabeta.

Rudi, Gunawan. 2013. Pendidikan IPS. Bandung: Alfabeta.

Rusman. 2010. Model-model Pembelajaran Mengembangkan Profesionalisme Guru. Bandung: RajaGrafindo Persada.

Sardiman. 2000. Interaksi dan Motivasi Belajar Mengajar. Jakarta: PT. RajaGrafindo Persada. 
Soetjipto, Raflis Kosasi. 2009. Profesi Kegurun. Jakarta: Rineka Cipta.

Sudjana.2005. Teknik Analisis Regresi dan Korelasi Para Peneliti. Bandung: Remaja Rosdakarya.

Sugiyono. 2008. Metode Penelitian Kuantitatif dan R\&D. Bandung: Alfabeta.

Sugiyono. 2009. Statistika Untuk Penelitian. Bandung: Alfabeta.

Suteja. 2009. Pendidikan Berbasis Al-Quran. Cirebon: Pangger Press.

Sutikno, M. Sobry. 2008. Belajar dan pembelajaran. Bandung: PT Remaja Rosdakarya.

Surapranata, Sumarna. 2004. Panduan Penulisan Tes Tertulis, Implimentasi Kurikulum 2004. Bandung: Rosdakarya.

Syah, Muhibin. 2009. Psikologi Pendidikan. Jakarta: Rajawali Pers.

Uno, Hamzah B. 2008. Teori Motivasi dan Pengukurannya. Jakarta: Bumi Aksara.

Uno, Hamzah B. 2011. Profesi Kependidikan. Jakarta: Bumi Aksara. 